\title{
Hubungan Intensitas Pemanfaatan Perpustakaan Terhadap Hasil Belajar Mahasiswa: Study Kasus pada UPT Perpustakaan Universitas Muhammadiyah Bengkulu
}

\author{
Meri Susanti R, S.I.Pust \\ Pustakawan Universitas Muhammadiyah Bengkulu \\ e-mail: merisyahril3@gmail.com
}

\begin{abstract}
Teaching and learning activities take place both in either a classroom with a lecturer or outside of classroom such as at home and library to achieving educational goals. In the process of teaching and learning in the campus lecturers are required to perform optimally the curriculum that has been set in the form of syllabus. One of the components contained in the syllabus is teaching methods as well as the means and resources of the lessons that will be given to the students, who have an important role in implementing the learning process to achieve the set goals. Library has an important role in supporting the learning materials required by students and support the smooth teaching and learning process so that the goals set can be achieved. The attainment of this goal for the personal development of students educates themselves on an ongoing basis to solve problems and enhance social attitudes. The existence of UPT Library at the University of Muhammadiyah Bengkulu is very important because teaching and learning activities are generally limited and incomplete and often is a new supporter for the development of student lessons. So clearly the essence of UPT UMB library is the center of learning resources and information sources. From the observation, many students of Muhammadiyah University of Bengkulu were still very rarely visit the library, and they had lack of interest in reading. Based on these problems, the writer was interested in raising the title "Intensity of Library Exposure to Students Learning Outcomes (Case Study of Muhammadiyah University of Bengkulu). The formulation of the problem was how the Intensity Relationship Utilization UPT Library University of Muhammadiyah Bengkulu and how the results of student learning University of Muhammadiyah Bengkulu. The purpose of this study to determine the relationship of Intensity Utilization of UPT Library University of Muhammadiyah Bengkulu and to know the results of student learning University of Muhammadiyah Bengkulu
\end{abstract}

Key Words: Utilization of Academic Library, Academic Library and Student Learning Outcomes 


\begin{abstract}
Abstrak
Aktivitas proses belajar mengajar berlangsung baik di dalam kelas melalui para dosen maupun di luar kelas seperti di rumah dan perpustakaan dengan maksud untuk mencapai tujuan pendidikan. Dalam proses belajar mengajar di kampus dosen dituntut untuk melaksanakan secara optimal kurikulum yang telah ditetapkan berupa silabus. Salah satu komponen yang terdapat dalam silabus tesebut adalah metode pengajaran serta sarana dan sumber dari pelajaran yang akan diberikan kepada mahasiswa, yang mempunyai peranan penting dalam melaksanakan proses belajar untuk mencapai tujuan yang ditetapkan. Perpustakaan mempunyai peranan penting dalam menunjang bahan belajar yang diperlukan oleh mahasiswa serta menunjang kelancaran proses belajar mengajar sehingga tujuan yang ditetapkan dapat tercapai. Pencapaian tujuan ini untuk pengembangan pribadi mahasiswa mendidik diri sendiri secara berkesinambungan untuk memecahkan segala masalah dan mempertinggi sikap sosial. Keberadaan UPT Perpustakaan di Universitas Muhammadiyah Bengkulu sangat penting artinya karena kegiatan belajar mengajar pada umumnya bersifat terbatas dan kurang tuntas bahkan sering kali baru merupakan penggerak bagi perkembangan pelajaran mahasiswa. Jadi jelas hakikat UPT perpustakaan UMB adalah pusat sumber belajar dan sumber informasi. Dari hasil pengamatan banyak mahasiswa Universitas Muhammadiyah Bengkulu masih sangat rendah untuk berkunjung ke perpustakaan, dan masih kurangnya minat baca mahasiswa.Berdasarkan permasalahan tersebut, maka penulis tertarik mengangkat judul "Hubungan Intensitas Pemanfaatan Perpustakaan Terhadap Hasil Belajar Mahasiswa (Study Kasus Univeristas Muhammadiyah Bengkulu). Rumusan masalah Bagaimana Hubungan Intensitas Pemanfaatan UPT Perpustakaan Universitas Muhammadiyah Bengkulu dan bagaimana hasil belajar mahasiswa Universitas Muhammadiyah Bengkulu. Tujuan penelitian ini untuk mengetahui Hubungan Intensitas Pemanfaatan UPT Perpustakaan Universitas Muhammadiyah Bengkulu dan untuk mengetahui hasil belajar mahasiswa Universitas Muhammadiyah Bengkulu
\end{abstract}

Kata Kunci : Pemanfaatan Perpustakaan, Perpustakaan Akademis dan Hasil Belajar Mahasiswa 


\section{Latar Belakang}

Hasil belajar mahasiswa sangat dipengaruhi oleh aktivitas belajar yang dilakukannya. mahaiswa yang aktif, rajin, dan tekun dalam kegiatan pembelajaran akan mampu meningkatkan hasil belajarnya sedangkan mahasiswa yang kurang aktif dalam kegiatan pembelajaran sulit untuk meningkatkan hasil belajar.

Aktivitas belajar berlangsung baik di dalam kelas melalui para dosen maupun di luar kelas seperti di rumah dan perpustakaan dengan maksud untuk mencapai tujuan pendidikan. Dalam proses belajar mengajar di kampus dosen dituntut untuk melaksanakan secara optimal kurikulum yang telah ditetapkan berupa silabus. Salah satu komponen yang terdapat dalam silabus tesebut adalah metode pengajaran serta sarana dan sumber dari pelajaran yang akan diberikan kepada mahasiswa, yang mempunyai peranan penting dalam melaksanakan proses belajar untuk mencapai tujuan yang ditetapkan.

Aktivitas akan lebih baik dan terarah apabila didukung oleh bahan belajar yang yang memadai dan lengkap. Sumber belajar yang dapat memberikan bahan belajar dan fasilitas belajar yang dapat dipergunakan dalam proses belajar mengajar adalah perpustakaan.

Perpustakaan mempunyai peranan penting dalam menunjang bahan belajar yang diperlukan oleh mahasiswa serta menunjang kelancaran proses belajar mengajar sehingga tujuan yang ditetapkan dapat tercapai. Pencapaian tujuan ini untuk pengembangan pribadi mahasiswa mendidik diri sendiri secara berkesinambungan untuk memecahkan segala masalah dan mempertinggi sikap sosial. Keberadaan UPT Perpustakaan di Universitas Muhammadiyah Bengkulu) sangat penting artinya karena kegiatan belajar mengajar pada umumnya bersifat terbatas dan kurang tuntas bahkan sering kali baru merupakan penggerak bagi perkembangan pelajaran mahasiswa.

UPT Perpustakaan UMB memberikan sumbangan yang sangat besar dalam upaya meningkatkan aktivitas mahasiswa serta meningkatkan kualitas pendidikan dan pengajaran dengan menyediakan sumber-sumber informasi baik cetak maupun elektronik. Melalui perpustakaan mahasiswa dapat berinteraksi dan terlibat langsung baik secara fisik maupun mental dalam proses belajar. UPT Perpustakaan UMB merupakan bagian integral dari program Universitas 
Muhammadiyah Bengkulu secara keseluruhan, di mana bersama-sama dengan komponen pendidikan lainnya turut menentukan keberhasilan proses pendidikan dan pengajaran di Unuversitas Muhammadiyah Bengkulu.

Dari hasil pengamatan banyak mahasiswa Universitas Muhammadiyah Bengkulu masih sangat rendah untuk berkunjung ke perpustakaan, dan masih kurangnya minat baca mahasiswa, apalagi membiasakan membaca buku yang berhubungan dengan buku-buku pendukung mata kuliah di perpustakaan. Mereka kurang memiliki kemampuan seperti yang diharapkan dikarenakan rendahnya kunjungan keperpustakaan, menunjukkan bahwa budaya membaca mahasiswa rendah dan berdampak pada proses pembelajaran. Untuk mengatasi hal tersebut diperlukan usaha untuk peningkatan aktivitas mahasiswa yakni memanfaatkan perpustakaan.

Berdasarkan permasalahan di atas, maka penulis tertarik untuk mangangkat judul "Hubungan Intensitas Pemanfaatan Perpustakaan Terhadap Hasil Belajar Mahasiswa (Study Kasus UPT Pesrpustakaan Univeristas Muhammadiyah Bengkulu).

Rumusan Masalah adalah Bagaimana Hubungan Intensitas Pemanfaatan UPT Perpustakaan Universitas Muhammadiyah Bengkulu ?Bagaimana hasil belajar mahasiswa Universitas Muhammadiyah Bengkulu?

\section{Kajian Teori}

\section{Pengertian Intensitas}

Intensif adalah suatu kegiatan yang dilakukan secara sungguhsunggu,terus-menerus, secara rutin dalam melakukan sesuatu hingga memperoleh hasil yang optimal. Intensif juga merupakan suatu aktivitas yang dilakukan secara secara terus-menerus dan berkelanjutan. Dengan demikian rutinitas sepertinya sudah memaku pada suatu aktivitas tertentu(Depdikbud, 1996).

Setiap hal yang dilakukan secara rutin disebut kegiatan rutinitas. Kegiatan rutinitas yang dilakukan secara terus-menerus dapat memberikan dampak positif (prestasi, penghargaan, dll).

Berdasarkan pengertian diatas, intensitas dapat diartikan sebagai seberapa besar respon individu atas suatu stimulus yang 
diberikan kedapannya ataupun seberapa sering melakukan suatu tingkah laku.

Dalam penelitian ini, istilah intensitas diartikan sebagai rutinitas atau seberapa sering siswa memanfaatkan perpustakaan sekolah.

\section{Pengertian Perpustakaan}

Perpustakaan adalah suatu ruangan atau bagian dari gedung atau bangunan atau gedung itu sendiri yang berisi buku-buku koleksi yang diatur dan disusun sedemikian rupa sehingga mudah untuk dicari dan dipergunakan apabila sewaktu-waktu diperlukan oleh pembaca (Basuki Sulistyo, 1991). Perpustakaan juga dapat di artikan kumpulan atau bangunan fisik sebagai tempat buku dikumpulkan dan disusun menurut sistem tertentu atau keperluan pemakai (Lasa Hs, 2006)

Dari pengertian di atas dapat disimpulkan perpustakaan adalah suatu unit kerja yang menyimpan berbagai macam koleksi bahan pustaka baik cetak maupun non cetak yang disusun secara sistematis sehingga dapat di manfaatkan oleh pemustaka sebagai sumber informasi.Di perguruan tinggi,perpustakaan di kenal sebagai "jantungnya" perguruan Tinggi,

Bila diperhatikan secara cermat, dari batasan-batasan yang telah diberikan para ahli di atas dapat disimpulkan bahwa intensitas pemanfaatan perpustakaan itu pada prinsipnya adalah segala sesuatu yang dapat membantu, memperlancar proses belajar-mengajar dan mempermudah tercapainya keberhasilan belajar.

\section{Peran Perpustakaan}

Secara garis besar peran perpustakaan adalah sebagai :

1. Mengumpulkan, menyimpan ,menyediakan informasi dalam bentuk tercetak ataupun dalam bentuk elektronik dan multimedia kepada pemustaka/user.

2. Menyediakan informasi yang dapat di akses lewat internet, namun harus pula menyediakan peraturan-peraturan yang dapat melindungi kepentingan perpustakaan dan keamanan informasi tersebut.

3. Terus memperhatkan kemajuan zaman dan kemajuan teknologi agar keinginan masyarakat dalam mengakses informasi dapat terpenuhi. 
4. Harus mampu menjadi jembatan penyedia informasi pada masa lalu, masa kini dan masa depan.

5. Perpustakaan harus terus mencari jalan agar tetap tanggap secara efektif dan inovatif terhadap lingkungan yang beragam dalam memenuhi harapan pengguna.

1. Fungsi Perpustakaan

Perpustakaan bagi perguruan tinggi dalah sarana penunjang yang sudah selayaknya diperhatikan dengan baik, walaupun merupakan sarana penunjang, fungsi perpustakaan bagi perguruan tinggi sangatlah vital seperti jantung dalam tubuh manusia. Salah satu fungsi perpustakaan adalah mencerdaskan anak bangsa dengan upaya pengelolaan perpustakaan agar masyarakat pengguna gemar membacadan mau mengunjungi perpustakaan. Fungsi perpustakaan dari masa ke masa mengalami perubahan dan perkembangan namun pada dasarnya fungsi perpustakaan(Saleh Abdul Rahman, 2012) adalah sebagai berikut:

\section{Fungsi Edukatif}

Perpustakaan berfungsi sebagai tempat untuk belajar mandiri, dimana pemustaka dapat mencari bahan-bahan yang dibutuhkan untuk menambah wawasan dan ilmu. Dengan fungsi edukatif ini perpustakaan sangat membantu pemerintah dalam program gemar membaca dan mencerdaskan kehidupan bangsa dengan belajar sepanjang hayat.

\section{Fungsi Informatif}

Perpustakaan mempunyai fungsi informatif, artinya informasi yang dibutuhkan oleh pemustaka dapat dicari di perpustakaan. Informasi bisa bersifat ilmiah, semi ilmiah.

\section{Fungsi Penelitian}

Artinya sumber-sumber informasi yang ada di dalam perpustakaan dapat digunakan sebagai bahan rujukan untuk melakukan penelitian. Berbagai informasi dapat dijadikan dasar untuk proposal penelitian

Fungsi Riset, penunjang penelitian (tinjauan pustaka) yang hasilnya dapat diambil menjadi bahan pertimbangan untuk menarik kesimpulan dan sarana dari suatu penelitian . 


\section{Fungsi Kultural.}

Perpustakaan mempunyai fungsi kultural artinya perpustakaan memiliki dan menyedikan bahan pustaka baik cetak maupun elektronik yang menyajikan kebudayaan daerah, kebudayaan suatu bangsa ataupun kebudayaan antarbangsa.Di perpustakaan juga tersimpan koleksi hasil karya budaya manusia dari masa ke masa yang dapat dijadikan rujukan untuk mempelajari sejarah peradapan manusia.

\section{Fungsi Rekreatif}

Perpustakaan mempunyai fungsi rekreasi artinya, pengguna dapat mencari koleksi yang bersifat populer dan menghibur dan pengguna dapat menggunakan media audio visual (TV, Video CD) serta koran yang di sediakan di perpustakaan, perpustakaan juga menyediakan taman dan mendekorasi ruang perpustakaan menjadi tempat yang nyaman bahkan ada yang dilengkapi dengan toko buku, warung warnet,swlayan mini ( mini market).

2. Karakteristik Perpustakaan yang Ideal

Perpustakaan sebagai salah satu sumber belajar dan dapat berfungsi dengan baik dan dapat menjalankan perannya apabila memenuhi beberapa kiteria yang harus dipenuhi. Perpustakaan dapat memberi pelayanan dengan baik apabila dlakukan dengan :

a. Cepat, artinya untuk memperoleh pelayanan otang tidak perlu menunggu terlalu lama;

b. Tepat waktu, artinya orang dapat memperoleh kebutuhan tepat pada waktunya;

c. Benar, artinya pelayanan membantu perolehan sesuatu dengan yang dibutuhkan

d. Up to date, artinya informasi yang disediakan lengkap, akurat, dan terbaru.

Perpustakaan yang direncanakan dengan baik dan matang akan membuatnya dapat berfungsi secara efisien dn efektif, memudahkan pemustaka ( user) dan petugas, menyediakan lingkungan yang kondusif, nyaman, menyenangkan, dan menarik sebagai tempat belajar dan bekerja. 


\section{Pengertian Hasil Belajar}

Hasil belajar adalah kemampuan yang dimiliki mahasiswa setelah ia menerima pengalaman belajarnya. Menurut Sumadi Suryabrata "hasil belajar adalah suatu proses yang dinyatakan dalam bentuk kuantitatif, yang khusus dipersiapkan untuk proses evaluasi (Suryabrata, 2002 : 54).

Maka dapat disimpulkan bahwa hasil belajar adalah penguasaan pengetahuan atau keterampilah yang dikembangkan oleh mata pelajaran dengan melalui ajaran-ajaran tertentu, hasil ditunjukan dengan nilai tes atau nilai angka yang diberikan guru. Prestasi belajar mahasiswa di perguruan tinggi umumnya diukur dengan Indeks Prestasi Kumulatif (IPK). Alfan dan Othman (2005) dalam Uyar dan Gungormus (2011) menyatakan bahwa kemampuan mahasiswa dalam perguruan tinggi juga menjadi perhatian perusahaan yang sering dikatakan sebagai "end user" dalam rantai pasokan lulusan untuk pasar tenaga kerja..

4. Faktor-faktor yang Mempengaruhi Hasil Belajar

\section{Faktor Keluarga}

Siswa yang belajar akan menerima pengaruh dari keluarga berupa cara orang tua mendidik, relasi antara anggota keluarga, suasana rumah tangga, keadaan ekonomi keluarga serta pengertian orang tua bisa berpengaruh terhadap hasil belajar siswa/ anak-anaknya.

2. Faktor Kampus

Faktor kampus yang mempengaruhi ini mencangkup metode belajar, kurikulum, relasi dosen dan mahasiswa, relasi mahasiswa dengan mahasiswa, disiplin kampus, pelajaran, dan waktu kuliah, standar pelajaran, keadaan gedung, dan tugas rumah.

3. Faktor Masyarakat

Masyarakat berupa faktor eksternal yang juga berpengaruh terhadap hasil belajar mahasiswa. Pengaruh itu terjadi karena keberadaannya mahasiswa dalam masyarakat. Kegiatan masyarakat seperti bentuk kehidupan masyarakat, teman bergaul dan mass media semuanya mempengaruhi hasil belajar.

Berdasarkan uraian di atas dapat disimpulkan bahwa syaratsyarat belajar dengan baik adalah : kesehatan jasmani, rohani, lingkungan yang tenang, tempat belajar yang menyenangkan, dan tersedia cukup bahan. Dan juga menjelaskan faktor-faktor yang mempengaruhi hasil belajar diantaranya faktor internal dan eksternal. 
Faktor internal diantaranya adalah faktor jasmani seperti kesehatan, cacat tubuh dan faktor psikologis seperti intelegensi, perhatian, minat, bakat, motif, kematangan dan kesiapan. Sedangkan faktor eksternalnya adalah faktor keluarga, faktor kampus dan faktor masyarakat. Apabila semua syarat dan faktor-faktor tersebut mendukung maka proses belajar akan berhasil, begitu juga sebaliknya. Apabila syarat dan faktor-faktor tersebut tidak mendukung maka proses belajarnya akan terhambat karena hal itu semua dapat berpengaruh terhadap hasil belajar mahasiswa.

\section{Hubungan Antara Intensitas Pemanfaatan Perpustakaan terhadap Hasil Belajar mahasiswa}

Belajar merupakan proses yang mengakibatkan perubahanperubahan. Proses tersebut dilakukan baik secara formal maupun informal. Secara formal, berarti seseorang melalui tahapan belajar pada suatu lembaga tertentu secara resmi dikelola oleh manusia tertentu dan mengikuti suatu model pembelajaran tertentu pula.

Belajar adalah proses usaha yang dilakukan untuk memperoleh suatu perubahan tingkah laku yang baru secara keseluruhan, sebagai hasil pengalamannya sendiri dalam iinteraksi dengan lingkungannya.

Hasil belajar berupa kabapilitas. Setelah belajar orang memiliki keterampiln, pengetahuan, sikap, dan nilai. Sedangkan menurut Piaget belajar merupakan pengetahuan yang dibentuk oleh individu dengan melakukan interaksi-interaksi terus-menerus dengan lingkungan, makan fungsi intelek akan berkembang. Ini berarti bahwa berhasil atau gagalnya pencapaian tujuan pendidikan itu sangat tergantung pada proses belajar yang dialami siswa, baik ketika ia berada di sekolah, maupun liingkungan rumah, atau peluarga sendiri.

Memahami pengertian belajar tersebut dapat diperoleh unsurunsur atau hal yang mendasar yang terdapat dalam kegiatan belajar, yaitu belajar adalah aktivitas fisik ataupun psikis, belajar sebagai proses dan menghasilkan perubahan.

Belajar-mengajar sebagai suatu proses yang merupakan suatu sistem yang tidak lepas dari komponen-komponen lain yang saling berinteraksi di dalamnya. Salah satu komponen dalam proses tersebut adalalah sumber belajar. Sumber belajar adalah daya yang bisa dimanfaatkan untuk proses kepentingan belajar-mengajar seperti perpustakaan. 
UPT Perpustakaan Muhammadiyah Bengkulu merupakan suatu fasilitas yang diberikan oleh pihak Universitas untuk menunjang proses belajar mengajar peserta didik sehingga perpustakaan harus dimanfaatkan seoptimal mungkin.

Perpustakaan yang mampu menjalankan fungsi dan tujuannya dengan baik akan mampu menyediakan informasi yang dibutuhkan oleh mahasiswa. mahasiswa akan senang berhubungan dengan perpustakaan karena perpustakaan akan mampu memenuhi kebutuhannya. Kegiatan siswa dalam memperoleh informasi merupakan tahapan awal dalam proses belajar yaitu tahapan memperoleh/penerimaan informasi.

Hubungan perpustakaan dalam proses dalam proses belajar tergantung pada kemampuan perpustakaan dalam menjalankan fungsinya serta adanya kebutuhan dan usaha siswa untuk memperoleh informasi dalam memenuhi kebutuhan tersebut. Siswa mempunyai kebutuhan untuk memperoleh informasi dan kebutuhan tersebut dipenuhi oleh perpustakaan. Perpustakaan membutuhkan mahasiswa untuk dapat Menjalankan fungsi dengan baik

1. Intensitas Mahasiswa Dalam Pemanfaatan Perpustakaan

Perpustakaan mempunyai peran yang besar dalam mendukung proses pembelajaran sehingga tujuan pembelajaraan yang telah ditetapkan dapat tercapai. Perpustakaan mempunyai hubungan terhadap pencapaian hasil belajar siswa, kemampuan membaca, dan kemampuan belajar mandiri. Oleh karena itu sudah selayaknya perpustakaan mendapat perhatian yang serius sebagai bagian tak terpisahkan dari sistem pendidikan.

Perpustakaan perguruan tinggi atau perpustakaan universitas adalah perpustakaan yang didirikan di lingkungan lembaga pendidikan tinggi untuk mendukung proses belajar-mengajar mahasiswa dan tenaga akademis. Keberadaan perpustakaan perguruan tinggi merupakan sarana yang diperuntukan agar proses belajar-mengajar lebih bersifat aktif dan dinamis. Dengan demikian, perpustakaan perguruan tinggi tidak hanya berguna bagi dosen saja dalam kaitannya untuk mempersiapkan bahan yang akan diajarkan, melainkan juga berguna bagi para mahasiswa dalam rangka melengkapi bahan-bahan yang diterima dikelas. Oleh karena itu, dosen harus mampu mengarahkan dan memberikan motivasi agar para mahasiswa lebih mendayagunakan perpustakaan, yang merupakan salah satu faktor yang menentukan bagi keberhasilan pendidikan, usaha-usaha ke arah perbaikan dalam pengembangan sistem 
dan layanan perpustakaan harus dilakukan dalam rangka menjadikan perpustakaan sebagai salah satu pusat sumber belajar. Jika dikaitkan dengan proses belajar mengajar di kampus, perpustakaan perguruan tinggi memberikan sumbangan yang sangat berharga dalam upaya meningkatkan aktivitas mahasiswa serta meningkatkan kualitas pendidikan dan pengajaran.

Melalui penyediaan perpustakaan, mahasiswa dapat berinteraksi dan terlibat langsung baik secara fisik maupun mental dalam proses belajar. Perpustakaan perguruan tinggi merupakan bagian integral dari program universitas secara keseluruhan, dimana bersama-sama dengan komponen pendidikan lainnya turut menentukan keberhasilan proses pendidikan dan pengajaran. Melalui perpustakaan mahasiswa dapat mendidik dirinya secara berkesinambungan.

Jika dikaitkan dengan proses belajar mengajar di kampus, perpustakaan perguruan tinggi memberikan sumbangan yang sangat berharga dalam upaya meningkatkan aktivitas mahasiswa serta meningkatkan kualitas pendidikan dan pengajaran. Melalui penyediaan perpustakaan, mahasiswa dapat berinteraksi dan terlibat langsung baik secara fisik maupun mental dalam proses belajar. Perpustakaan perguruan tinggi merupakan bagian integral dari program universitas secara keseluruhan, dimana bersama-sama dengan komponen pendidikan lainnya turut menentukan keberhasilan proses pendidikan dan pengajaran. Melalui perpustakaan mahasiswa dapat mendidik dirinya secara berkesinambungan.

Pemanfaatan UPT Perpustakaan UMB diantaranya adalah kunjungan mahasiswa ke perpustakaan, membaca bahan pustaka, mencari sumber informasi dan meminjam buku di perpustakaan.

Berdasarkan hasil penelitian intensitas pemanfaatan perpustakaan dalam kategori intensif dalam memanfaatkan UPT perpustakaan UMB menujukkan bahwa masih ada mahasiswa yang aktif berkunjung ke UPT perpustakaan UMB, pada saat selesai perkuliahan, pada saat jam pelajaran kosong ataupun saat ada tugas. Selain itu, masih ada mahasiswa yang memanfaatkan waktu luang dengan membaca buku di perpustakaan dan meminjam buku di perpustakaan.

\section{Hasil Belajar Mahasiswa}

Hasil belajar adalah suatu proses yang dinyatakan dalam bentuk kuantitatif, khususnya dipersiapkan untuk proses evaluasi, misalnya IPK 
yang diperoleh mahasiswa(Suryabrata, 2002). Menurut Undang-Undang No 2 Tahun 1989 Pasal 35 bahwa salah satu sumber belajar adalah perpustakaan yang menjadi bahan ajar yang memuat ilmu pengetahuan dosen dan mahasiswa. Pemanfaatan perpustakaan sebagai sumber belajar akan memberikan ilmu pengetahuan kepada mahasiswa dan mampu meningkatkan hasil belajar mahasiswa.

3. Hubungan Intensitas Pemanfaatan Perpustakaan Terhadap Hasil Belajar Mahasiswa

Dengan memanfaatkan UPT Perpustakaan UMB mahasiswa lebih berwawasan, kreatif, dan inovatif dalam proses belajar di kampus. Hal ini sangat membantu mahasiswa dalam memencahkan masalah belajar yang dihadapi. Semakin sering mahasiswa memanfaatkan perpustakaan semakin tinggi prestasi yang diraih. Hal ini dapat dibuktikan bahwa mahasiswa yang sering mempergunakan perpustakaan lebih pintar dan selalu mendapat nilai yang lebih tinggi.

\section{Kesimpulan}

Berdasarkan pembahasan dalam penelitian ini maka dapat disimpulkan bahawa ada hubungan yang signifikan antara intensitas pemanfaatan perpustakaan terhadap hasil belajar mahasiswa universitas Muhammadiyah Bengkulu

\section{Daftar Pustaka}

Basuki Sulistyo. (1991). Pengantar Ilmu Perpustakaan. Jakarta: Gramedia. Depdikbud. (1996). (KBBI) Kamus Besar Bahasa Indonesia. Jakarta: Balai Pustaka.

Lasa Hs. (2006). Membina Perpustakaan Madrasah dan Sekolah Islam. Jakarta: Adicipta.

Saleh Abdul Rahman. (2012). Manajemen Perpustakaan PUST-2229. Jakarta: Universitas Terbuka.

Suryabrata. (2002). Pengembangan tes hasil belajar. Diambil 3 Desember 2017, dari http://library.um.ac.id/freecontents/index.php/buku/detail/pengembangan-tes-hasil-belajar-sumadisuryabrata-20439.html 